\title{
СИНТЕЗ И АНТИМИКРОБНАЯ АКТИВНОСТЬ 3-НИТРО-4-АМИНО-АЗОЛО[5,1-С][1,2,4]ТРИАЗИНОВ
}

\section{Е.К. Воинков ${ }^{1}$, Н.П. Евстигнеева ${ }^{2}$, Е.Н. Уломский' ${ }^{1}$ В.Л. Русинов}

${ }^{1}$ Химико-технологический институт, Уральский федеральный университет им. первого Президента Б. Н. Ельцина, 620002, Россия, г. Екатеринбург, ул. Мира, 19.

2Уральский научно-исследовательский институт дерматовенерологии и иммунопатологии, 620076, Россия, г. Екатеринбург, ул. Щербакова, 8.

DOI: 10.19163/MedChemRussia2021-2021-238

voinkov-egor@mail.ru

Наиболее распространенным способом получения азоло[5,1-с][1,2,4]триазинов является сочетание диазоазолов с СН-активными азокомпонентами. Комбинация разнообразных азольных фрагментов с производными нитрилов позволила синтезировать широкий ряд 4-аминозоло[5,1-с][1,2,4]триазинов, обладающих различной биологической активностью. Представители этого ряда проявляют антиоксидантную[1], антимикробную [2], противоопухолевую [3], противогрибковую [4] и некоторые другие виды активностей.

3-Нитро-4-аминоазоло[5,1-с][1,2,4]триазины были получены с использованием доступной калиевой соли нитроацеторитрила[5].

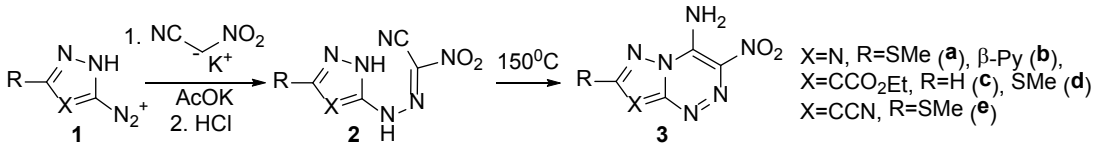

Для соединений 3 была исследована антимикробная активность в отношении эталонных штаммов клинически-значимых микроорганизмов.

\begin{tabular}{|c|c|c|c|c|c|c|c|c|}
\hline \multirow{2}{*}{$\begin{array}{l}\text { штаммы } \\
\text { ратеа- } \\
\text { раты }\end{array}$} & \multicolumn{8}{|c|}{ МИК, мкг/мл } \\
\hline & $\begin{array}{l}\text { E. coli } \\
\text { ATCC } \\
8739\end{array}$ & $\begin{array}{c}\text { C. braakii } \\
\text { ATCC } \\
101 / 57\end{array}$ & $\begin{array}{c}\text { S. flex-neri } \\
1 \mathrm{a} 8516\end{array}$ & $\begin{array}{c}\text { Pr. vul- } \\
\text { garis } \\
222\end{array}$ & $\begin{array}{c}\text { S. marce- } \\
\text { scens } \\
\text { ATCC } \\
13880\end{array}$ & $\begin{array}{c}\text { KL. pneu- } \\
\text { moniae } \\
\text { ATCC } \\
13883\end{array}$ & $\begin{array}{c}\text { P. aeru- } \\
\text { ginosa } \\
\text { ATCC } 9027\end{array}$ & $\begin{array}{c}\text { S. aureus } \\
\text { ATCC } \\
25923\end{array}$ \\
\hline $3 a$ & 31,2 & 62,5 & 31,2 & 125 & 62,5 & 62,5 & $>500$ & 62,5 \\
\hline $3 b$ & 62,5 & $>500$ & 31,2 & 125 & 250 & $>500$ & $>500$ & 31,2 \\
\hline $3 c$ & 125 & 500 & 250 & 250 & 500 & 500 & $>500$ & 125 \\
\hline $3 d$ & 500 & $>500$ & 500 & 500 & 500 & 500 & $>500$ & 125 \\
\hline $3 e$ & 125 & 250 & 31,2 & 62,5 & 250 & 250 & $>500$ & 62,5 \\
\hline
\end{tabular}

Как видно из таблицы, 3 из 5 соединений активны одновременно в отношении нескольких штаммов микроорганизмов.Таким образом, ряд 3-нитро-4-аминоазоло[5,1-с] $[1,2,4]$ триазинов заслуживает расширенного изучения антимикробной активности.

Работа выполнена при поддержкеМинистерства науки и высшего образования Российской Федерации, Грант № 075-15-2020-777.

\section{Литература}

[1] A. El-Mekabaty, A.A. Fadda. J. Heterocycl. Chem. 2018, 55, 2303.

[2] M.A. Metwally, M.A. Gouda, A.N. Harmal, A.M. Khalil. Eur. J. Med. Chem.2012,56, 254.

[3] R.A. Mekheimer, M.A. Al-Sheikh, H.Y. Medrasi, G.A.A. Bahatheg. Synth. Commun. 2017, 47, 1052

[4] M.A.Gouda. J. Heterocycl. Chem.2015,52, 990.

[5] E.K. Voinkov, E.N. Ulomskiy, V.L. Rusinov et al. Mendeleev Commun. 2016, $26,172$. 